LEFT OF HOLLYWOOD 
THIS PAGE INTENTIONALLY LEFT BLANK 


\section{Left of Hollywood}

Cinema, Modernism, and the

Emergence of U.S. Radical Film Culture

CHRIS ROBÉ 
Copyright (C) 2010 by the University of Texas Press

All rights reserved

Printed in the United States of America

First edition, 20IO

Portions of Chapter Two were first published as "Eisenstein in America: The iQue Viva México! Debates and the Emergent Popular Front in U.S. Film Theory and Criticism," Velvet Light Trap 54 (2004): I8-3I. Copyright (C) 2004 the University of Texas Press. All rights reserved. Portions of Chapter Two were also first published as "Revolting Women: The Role of Gender in Sergei Eisenstein's Qué Viva México! and U.S. Depression-Era Left Film Criticism," Jump Cut 48 (2006). Reprinted with the permission of the publisher. Chapter Four was first published as "Taking Hollywood Back: The Historical Costume Drama, the Biopic, and Popular Front U.S. Film Criticism," Cinema Journal 48, no. 2 (2009): 70-87. Copyright (C) 2009 the University of Texas Press. All rights reserved.

Requests for permission to reproduce material from this work should be sent to: Permissions, University of Texas Press, P.O. Box 7819, Austin, TX 78713-7819, www.utexas.edu/utpress/about/bpermission.html

(a) The paper used in this book meets the minimum requirements of ANSI/NISO Z39.48-I992 (RI997) (Permanence of Paper).

LIBRARY OF CONGRESS CATALOGING-IN-PUBLICATION DATA

Robé, Chris, 1972-

Left of Hollywood : cinema, modernism, and the emergence of U.S. radical film culture / Chris Robé. - Ist ed.

p. $\mathrm{cm}$.

Includes bibliographical references and index.

ISBN 978-0-292-72296-5 (cloth : alk. paper)

I. Motion pictures - Political aspects-United States-History-2oth

century. 2. Motion pictures-Social aspects-United States-

History-2oth century. 3. Motion picture industry-United StatesHistory -20 th century. 4. Socialism and motion pictures-United States. 5. Film criticism-United States-History - 2oth century. 6. Radicalism-United States-History-2oth century. 7. Politics in motion pictures. 8 . Working class in motion pictures. I. Title.

PNI995.9.P6R63 20IO

$791.43^{\prime} 658 \mathrm{I}-\mathrm{dc} 22$ 